\title{
A new portrait-head of Antoninus Pius from Egypt
}

\section{Abdel Hamid Masoud Ain Shams University}

\section{Introduction about finding}

The over-life-size portrait-head with which this article is concerned is kept now at Sohag Museum, Inv. 2097 (figs. 1-7). ${ }^{1}$ The Head's height is 0.45 m., width $0.33 \mathrm{~m}$; depth $0.34 \mathrm{~m}$. The portrait-head was found in 2018 by an Egyptian mission in Kom Ombo during the removal of the groundwater from a circular well used as a Nilometer ${ }^{2}$ to the north of the Mammisi in the Sobek and Horus temple. ${ }^{3}$ The limestone portrait-head was restored from many pieces especially the chin and the mouth, which had suffered much damage and were found very fragmentary (fig. 5). The large nose is almost completely chipped out, in addition to small chips on the eyebrows.

\section{The portrait}

The subject shows a middle-aged man, in frontal pose, with individual facial features, reflecting skilled workmanship in carving naturalistic portraits; it is mainly characterized in the drawn-down brows, and short fullgrown beard. The delicate features of the middle-aged man are obvious in the face, especially the soft forehead and the fleshy cheeks without visible

\footnotetext{
${ }^{1}$ I would like to express here my gratitude to Elham Salah, head of the Museums sector in the Ministry of Antiquities for giving me the permission to publish and study this head. Also my thanks are extended to the Sohag Museum management for presenting all possible facilities for this study.

${ }^{2}$ NEWSLETTER 2018, p. 1.

The portrait's identity was announced by the Egyptian mission as a portrait of Marcus Aurelius (161-180 A.D.).

${ }^{3}$ Kom Ombo or Ombos is a famous archaeological site during the Greco-Roman periods, setting on the eastern bank of the Nile between Luxor and Aswan, in the road to Aswan, almost $42 \mathrm{~km}$. north of Aswan, and about $165 \mathrm{~km}$. south of Luxor. In fact, the survival unique double temple consists of two independent and conjoined sanctuaries, the eastern one dedicated to the god Sobek and the western to Horus the Elder. KAMEL 1993, pp. 135-141; MACQUITTY 1976, pp. 28-9; MARKOT 2001, pp. 248-9; PORTMAN 2001.
}

Classical Papers, vol. xvii , 2020 


\section{A new portrait-head of Antoninus Pius from Egypt}

face wrinkles or thick flesh folds. Two nasal folds encircle the mouth. The eyes are almost almond-shaped and look forward. The eyebrows are lightly incised with individual hairs. The iris is cut in circular shape, but not complete, with pupil slightly disappearing beneath the upper eyelid. The mouth is closed with thin lips. The carving of the ears is executed out with a kind of drills. The frontal view with slightly looking upwards eyes give an expression of a serious and distant look, but without any specific attitude.

The Identity of the portrait-head owner is not difficult, because it has the standard features and hairstyle of Antoninus Pius.

\section{Type}

The hair, beard and moustache are well-dressed by experienced sculptor. The hairstyle is initially smooth; treated on the top and at the nape with simply, summarily and wavy chiseled curly hair locks, radiate from the skull center into different directions. Each hair lock is additionally treated with fine incision indicating hair delineation (figs.1, 4-7). Only over the forehead and over the nape does the movement of the hair increase, the curls become denser and higher. Over the forehead (figs. 1-2), the hair is combed forward and down in thick hair-locks descending with two crescent shaped central locks which are a characteristic of the Antoninus Pius portrait. ${ }^{4}$

Two curls on the sides are projecting obliquely towards outside. Then eight curls divided into four on every side are dressed between the central four locks and the ears, which in profile are characteristic of Antoninus Pius's images. There is also a particularly interesting hair motif above the upper part of both ears: the curls form a kind of fan whose tips curl up (figs. 4-6).

Details of the compact beard and moustache were carved with a degree of care similar to that shown in the treatment of the head locks on the front and round the face, but with finely shorter carved tufts (figs. 1, 3-5). The proficient artist rendered the beard and moustache with a great skill against the smoothness of the skin. The upper lip is topped with a tidy moustache arranged with incised semi-vertical curls around the mouth, parted in the middle of the upper lip, and the ends of the moustache strands extended to join the beard.

Antoninus Pius here has light, closely cropped, neat and tidy beard, which was carried out with modulated curls, presented as extensions of the hair ends on both sides in front of both ears. The beard reflects a treatment of

${ }^{4}$ KLEINER 1992, pp. 268-9; FITTSCHEN, ZANKER 1985, p. 64. 


\section{Abdel Hamid Masoud}

rare precise tufts arranged in several semi-vertical separated rows, every row contains about four tufts on the sides, but less in the middle, every tuft contains a lot of curly short locks. The drill has not been used at all in the curls of both beard and moustache.

In general, the appearance of Antoninus Pius's images followed the artistic Hadrianic traditions such as the curly coiffure on the front and the short curls of the beard, but with more plastically execution. ${ }^{5}$ Antoninus Pius follows Hadrian's fashion to reflect a physical affinity in appearance with his predecessor Hadrian. ${ }^{6}$

Typologically the numerous portraits of Antoninus Pius are classified into three main types, according to Max Wegner who distinguished these types in $1939,{ }^{7}$ which were accepted amongst scholars. ${ }^{8}$ These types are associated with the main age stages and essential events in the emperor's life. The earliest and best known type is the "Formia Type", 9 to which belongs this Kom Ombo portrait of Antoninus Pius.

The Antoninus Pius portrait discovered in Formia, and is kept now in the "Museo Nazionale delle Terme", is considered the archetype of the largest quantity of Antoninus Pius images from everywhere in the Roman Empire. Scholars identified about 18 examples of this type, showing the emperor with individual iconography and particular characteristics, especially the personal facial features and the central locks on the forehead. These two central fore-locks are the main criteria to attribute the Kom Ombo head to this type. ${ }^{10}$ This feature does correspond typically to the first graphic sketch, illustrated by Fittschen, ${ }^{11}$ forming the standard crescent-like shape. A close parallel of the Kom Ombo head is kept in Musée Saint-Raymond showing in particular the treatment of the front hair locks. ${ }^{12}$ The Kom Ombo head is

\footnotetext{
${ }^{5}$ KLEINER 1992, p. 268.

${ }^{6}$ WALKER 1995, p. 14.

${ }^{7}$ WEGNER 1939, pp. 16-25.

${ }^{8}$ FITTSCHEN, ZANKER 1985, p. 64; KLEINER 1992, p. 268.

${ }^{9}$ Formia, named also Formiae, is a city which lies in Latium region, exactly on the coast of the Tyrrhenian Sea, on the ancient Appian Way, 88 miles from Rome. WISSOWA 1909, s.v. Formiae

${ }^{10}$ FITTSCHEN, ZANKER 1985, p. 64; KLEINER 1992, pp. 268-9, fig. 231; WEGNER 1939, pp. 16-22, 126-130.

${ }^{11}$ FITTSCHEN, ZANKER 1985, p. 64.

${ }^{12}$ Musée Saint-Raymond, Toulouse, Inv. MSR 30106. Found in the archaeological site ofChiragan, Martres-Tolosane, France, 1826-8. Total H. 42cm, H. of the head: $32 \mathrm{~cm}$, L. $25.5 \mathrm{~cm}$. SARTE 1997, p. 50, no. 22.
} 


\section{A new portrait-head of Antoninus Pius from Egypt}

comparable to other portraits of Antoninus Pius, such as an example from Asia Minor, ${ }^{13}$ especially the treatment of the thick curly hair-locks on the forehead, and the hair locks of the right side.

\section{Style}

The hair coiffure and curls details on the forehead and around the face were highlighted and rendered with a considerable interest and high degree of attention. The treatment of the hairstyle on the forehead, which has high quality of plasticity and individual locks, specifically, drilled locks, lighting, and producing contrasting shadows. The sculptor used a grooving tool and a drill to carry out the depth and intensive locks of the emperor's hair and to define the hair-line on the front, so each lock was formed by drilling the limestone material with a strict drill. Remains of drill holes and grooving tool can be seen in several areas within the locks and grooved lines.

Kom Ombo's portrait presents an over life-size imperial portrait-head carved by a skillful sculptor, most likely copying the same model of the only and well known effigy of Antoninus Pius from Egypt, which was found in el-Ashmunein (Hermopolis Magna - in Middle Egypt), kept now in the Cairo Egyptian Museum (figs. 8-9). ${ }^{14}$ This head presents many Antonine techniques and features, especially the incomplete circles of the drilled pupils and irises. It seems that the hair or at least, its details were added in plaster. The moustache divided in the center is another Antonine characteristic. Scholars agree that this head is a replica of an eastern model carved in Alexandria; that gives the head a distinctive character with a different psychological expression than the official metropolitan images of this emperor.

Both the Kom Ombo and el-Ashmunein heads belong to the Formia type in terms of facial features and hairstyle, with remarkable variations. Beside the material and size, the Ashmunein head depicts an older and more pathetic Pius, while the Kom Ombo head does not show the deep and folding nasal folds.

This stylistic variation perhaps indicates a local sculptor of the Kom Ombo head, or perhaps it was carved in a flourishing centre like nearby

\footnotetext{
${ }^{13}$ Found in Apollo temple area at Alabanda, 1905. Marble, H. total: $32.5 \mathrm{~cm}$. Kept now in the "Archaeological Museum of Istanbul", Inv. No. 1604. INAN, ROSENBAUM 1966, pp. 17, 74, cat. n ${ }^{\text {o. } 39, ~ p l . ~ x x v, ~ 2-3 . ~}$

${ }^{14}$ The Egyptian Museum, Cairo, Inv. JE. 41650, marble, H. 38 cm. GRAINDOR 1936, p. 53, no. 13, pls. XII a-b; GRIMM 1975, p. 20, pl. 37, 40; KISS 1984, p. 61, figs. 130-1; WEGNER 1939, pp. 17, 130.
} 


\section{Abdel Hamid Masoud}

Thebes. This sculptor used the simplified values of the Formia type, reduced plastically, even further than the Alexandrian replica. The Kom Ombo head shows a very linear and decorative treatment of the hair locks, softer and younger treatment of the facial skin, which is comparable to the portraits of Antoninus Pius on the Alexandrian coins impressed in richness that could have been derived from the stone portraits. ${ }^{15}$ The freer execution of the type may support the hypothesis that the head and its lost statue were carved far from Alexandrian influence, and indicate a wide spread of official imperial types, with many phases of reproduction in the different metropoleis of the provinces.

\section{Context \& Function}

It is not surprising therefore to find in Egypt or elsewhere all over the Roman Empire Antoninus Pius's in different artifacts, especially portraits for simple public and private purposes, or in other words, for political and economic considerations related to the empire policy or to Antoninus Pius himself as a beloved emperor and other emperors whose general policies include activities of erecting imperial statues, high economic level of the empire and Imperial visits, ${ }^{16}$ Also his popularity, his long reign, and great achievements both in Rome and the provinces. Antonius Pius's reign witnessed intensive architectural activity in Egypt and Alexandria, including various new structures and additions to old ones, ${ }^{17}$ but a large part of the walls decorations and religious buildings, in particular the Egyptian style structures, were in Upper Egypt and the Western Desert especially Kharga and Siwa Oases. ${ }^{18}$

\footnotetext{
${ }^{15}$ ASHTON 2004, nos. 17, 23-4, 28, 41, 62.

${ }^{16}$ HǾJTE 1966, p. 232.

17 McKENZIE 2007, p. 137.

${ }^{18}$ Antonius Pius built temples in Upper Egypt and Oases including Egyptian-style one at Kom Mer dedicated to Anuket and a chapel dedicated to Isis at el-Hilla, both located South and Southeast of the famous temple of Esna. He also completed, after Trajan, building and decorating a birth-temple of Bes at Dendera. In addition there are a portal at Armant and an entrance kiosk at the temple of Amun at Medinat Habu, and also some important architectural additions in the temple of Isis at Deir el-Shelwit. His name was mentioned frequently on the walls of the survived building in Esna temple beside other emperors, in particular Marcus Aurelius and Commodus. And there are indications that the decorations of these walls began with the reign of Antoninus Pius. He also continued the wall-decoration of the temple of Montu at Medamud. One of the Osirian chambers in the temple of Philae
} 


\section{A new portrait-head of Antoninus Pius from Egypt}

As mentioned above, Kom Ombo's portrait-head was found in the nilometer of Kom Ombo temple during cleaning and decreasing the level of groundwater from it. Let us agree that the head found in this archaeological context is not in its original location, and the existence of the head portrait at the bottom of the nilometer does not allow us to reach the right archaeological context conclusion. In addition to this, the archaeological evidence has not yet been revealed to tell us the kind of relationship between the emperor and such an unusual location.

Despite the above mentioned circumstances, and according to the portraithead's size and care taken in its execution, it must have a very important function. The portrait provenance as well can help us recognize the main aim of the work. So the researcher suggests that the Kom Ombo's portraithead was originally a part of a bust or a complete statue, and that it was sculptured separately to complete a bust/statue erected as usual inside a religious Roman-style structure such as a temple or a shrine built close to the main Egyptian-style temple in honor of a particular event or in the context of the Imperial cult. Apparently the event could not be a visit of the emperor to Egypt, as Antoninus Pius never left Italy during his reign. ${ }^{19}$ Similarity, it was suggested that, the bust/statue to which belonged the portrait of Antoninus Pius from el-Ashmunein was erected in a building at Hermopolis Magna. ${ }^{20}$

On one hand, various excavations in Egypt uncovered a rich series of portraits of emperors and members of the Imperial family, including a collection of heads, busts and complete statues. ${ }^{21}$ Certainly, a number of the

was built by Antoninus Pius. A temple at Kom el-Nadura, about $2 \mathrm{~km}$. south of Kharga Oasis is dated to Antonius Pius reign, and also at Qasr Zayan, there is a temple of Amun, dated to the Ptolemaic and Roman periods, exactly from the reign of Antonius Pius, likewise Roman style buildings, including a temple erected at Tuna el-Gebel, possibly dedicated to Sarapis, and another one at Siwa. ASHTON 2004, pp. 10-11; FRANKFURTER 1998, p. 127; MACQUITTY 1976, p. 32, 150; McKENZIE 2007, pp. 140 f; WEGNER 1939, p. 17; WILKINSON 2000, p. 199, 236-8; WILLEITNER 2003, pp. 41-4.

${ }^{19}$ HǾJTE 1966, pp. 231-2.

${ }^{20}$ GRAIDOR 1936, p. 53, no. 13, pls. XII a-b.

${ }^{21}$ GRAIDOR 1936, pp. 4-72, pls. I-XIII, XV-XXI; GRIMM 1975, p. 20, cat. Nos. 21-2, pls. 37, 38-9, 40; KISS 1984, pp. 33-37, 42, 45, 47, 50 f, 54, 56, 58-9, 61, 64, 66, 72, 86, figs. 29-30, 34-5, 46-7, 63-4, 74-5, 85-6, 88-9, 94-7, 104-105, 111-112, 114-117, 120-1, 130-1, 147-9, 160, 179-180, 220-1; WALKER, HIGGS 2001, nos. 318-321, 323. 


\section{Abdel Hamid Masoud}

owners of these images played political and religious roles according to the archaeological and textual evidence. May be the erecting of the Imperial portraits in Egypt was to serve the political propaganda concept, or as continuation of a Roman habit ${ }^{22}$, or was ancient Egyptian tradition going back to the dynastic or Ptolemaic periods. According to archaeological evidence and documents from Ptolemaic Egypt, in particular the decrees of Canopus, Raphia, and Rosetta, it is true that all Egyptian towns have cult places of the Ptolemaic kings and their families' members beside the main temples of gods, in keeping with an ancient Egyptian practice. ${ }^{23}$

On the other hand, like the Ptolemaic rulers, multiple indications refer to the organization of an Imperial cult in a series of temples and shrines, as Caesarea, Sebasteia ${ }^{24}$, or even Hadrianeia. ${ }^{25}$ These temples were structured in both of the metropoleis and capitals of nomes, as well as few villages from Alexandria to Aswan, ${ }^{26}$ but the Caesareum of Alexandria was the most famous one in this concept, and it contained both a naos and a temenos. ${ }^{27}$ As a result, and the documents confirmed that, several imperial idols have been erected inside the previous temples, as well as in the Egyptian or GrecoRoman temples and shrines alongside the supreme those of gods throughout Egypt. ${ }^{28}$

The possibility of the portrait-head from Kom Ombo with its statue being erected inside a Roman-style temple or a shrine for the imperial cult is based on some factors. Firstly, Dundas supposed that the offerings and sacrifice

\footnotetext{
${ }^{22}$ COONEY, J. D. 1967, p. 20.

${ }^{23}$ FISHWICK1989, pp. 337ff; OTTO 1905, p. 11; OTTO 1908, pp. $261 \mathrm{ff}$.

${ }^{24}$ PFEIFFER 2010, pp. $237 \mathrm{ff}$.

${ }^{25}$ PFEIFFER 2010, pp. $257 \mathrm{f}$.

${ }^{26}$ Many imperial temples under varied names, like Caesareum or Hadrianeion, were built throughout Egypt. For examples, one was built in the city of Canopus to the east of Alexandria, and a temple of Hadrianeion was in Memphis. Some of these buildings were in the towns and villages of Fayoum like Arsinoe and Philadelphia. Cultural centers in Middle Egypt had such temples; we know at least three imperial cult-buildings attested at Oxyrhynchus. Also Antinoopolis and Hermopolis Magna had Caesareum and Hadrianeion. There are indications to temples of the imperial cult in Heptacomia, Herakleopolis, and Lykopolis. DUNDAS 1994, pp. 159-160-7, 170; PFEIFFER 2012, p. 91.

${ }^{27}$ DUNDAS 1994, pp. 132, 136-154; McKENZIE 2007, pp. 177 f; PFEIFFER 2010, p. $37 \mathrm{ff}$.

${ }^{28}$ FISHWICK1989, pp. 336, 342.
} 


\section{A new portrait-head of Antoninus Pius from Egypt}

were practiced in imperial temples in the Ombite and Elephantine nomes, ${ }^{29}$ and sure these temples had imperial statues. The scenes of Khnum temple at Elephantine indicate that this Egyptian temple had additions in the Roman period and that the last decorations in the temple were carried out by the time of Antoninus Pius. ${ }^{30}$ The same applies to Kom Ombo temple. By the Roman period the forecourt and outermost parts had been structured, ${ }^{31}$ and we found scenes and texts within the reliefs of the northern section of the outer passage in the temple related to emperors of the Antonine dynasty, including names of Antoninus Pius, Marcus Aurelius, Lucius Verus, and Commodus, beside other emperors. ${ }^{32}$

Royal Ptolemaic statues were placed in the Kom Ombo temple according to a hieroglyphic text from the temple dated to the reign of Ptolemy VI Philometor (180-145 BC.). It seems that the same practice continued during the Roman era without stop, and that the royal Ptolemaic and imperial images were to appear during various festive occasions. ${ }^{33}$

The supposed imperial temple in Kom Ombo can be compared with other attested cases built close to native temples. The well-known tetrastyle temple of August at Philae with its typical Roman form beside the Egyptian temple of Philae represents a clear example for the imperial cult temples in Upper-Egypt, and an inscription dated to the reign of Vespesian mentioned that the local inhabitants dedicated a statue of the emperor in this temple. ${ }^{34}$

A great Roman-style Imperial cult shrine was excavated before the first pylon of the Amun temple at Karnak in Thebes; this temple was certainly

\footnotetext{
${ }^{29}$ DUNDAS 1994, pp. 171-2.

${ }^{30}$ KAMEL 1993, p. 44.

${ }^{31}$ The core structure of the Kom Ombo temple started with the reign of Ptolemy V Epiphanes (204-180 BC.) or Ptolemy VI, and most of the decorations were carried out by the later Ptolemaic rulers and some of the Roman Emperors. The scenes and inscriptions of the temple included some Roman emperors such as Augustus, Claudius, Tiberius, as well as a shrine dedicated to Sobk by Caracalla. MARKOT 2001, pp. 249-250; PORTER, MOSS 1991: pp. 197-8, 201; WILKINSON 2000, p. 209.

${ }^{32}$ HÖLBL 2000, pp. 94-9.

${ }^{33}$ FISHWICK1989, p. 346.

${ }^{34}$ McKENZIE 2007, pp. 166 ff; PFEIFFER 2010, pp. 241 f; PFEIFFER 2012, p. 89.
} 


\section{Abdel Hamid Masoud}

connected to the temple of the Egyptian god Amun ${ }^{35}$, and a large number of the Imperial statues with their bases were found inside the cella of this temple, some of these bases are inscribed.

The richness of this series of emperors' images is mentioned by the papyri documents and temples' inventories of nomes such as Oxyrhynchus and Kynopolis in Middle Egypt from the reign of Caracalla. ${ }^{36}$ Each temple, both in the villages and cities of Egypt, has portraits of the Imperial family members.

Receipts of the Ostraca tell us that there were contributions for setting up busts and statues of the emperors which could be erected several times. Emperor Claudius himself had delegated the Alexandrians to erect statues on quadrigae in Taposiris, Pharos and Pelusium. An ostracon indicates that funds were gathered to pay the fairs for a statue of Hadrian, two years after his death during the reign of Antoninus Pius. ${ }^{37}$

The existence of imperial cults beside the native cults is not surprising. According to ancient Egyptian beliefs, the king as the descendant of gods shared their divinity and played an important part in religion. The same applies to Ptolemaic kings and then to the Roman emperors, ${ }^{38}$ the new pharaohs of Egypt. They are depicted in the scenes of the Egyptian temples as pharaohs with the same poses and followed by similar names and titles like the kings of the Dynastic and Ptolemaic periods.

\section{Date}

The head of Kom Ombo perhaps was carved in Pius' lifetime, as its accordance to the Formia type suggests early years of the emperor reign. The incised and incomplete eye-pupils inside a semi-round iris support an early Antonine date as well. Wegner dated the "Formia type" within the first years of Antoninus Pius (138 AD.). ${ }^{39}$ Scholars asserted that this type was created at the beginning of Antoninus Pius's reign, ${ }^{40}$ and its iconographic influence continued in portraits until $150 \mathrm{~A}$. D.

\footnotetext{
${ }^{35}$ PFEIFFER 2010, pp. 242 f; PFEIFFER 2012, pp. 89-90, fig. 6.3. Two bases can be attributed to August ( 27 B. C. -14 A D.) and other three bases belong to Claudius (41-54 AD.)

${ }^{36}$ FISHWICK1989, pp. 344-5; GRAIDOR 1936, p. 17.

${ }^{37}$ GRAIDOR 1936, pp. 17-18.

${ }^{38}$ DUNDAS 1994, p. 257.

${ }^{39}$ WEGNER 1939, p. 23.

${ }^{40}$ KLEINER 1992, p. 268.
} 


\section{A new portrait-head of Antoninus Pius from Egypt}

The Pius portrait from Kom Ombo in terms of its hair stylizing is comparable to a mummy-portrait of a soldier in the British museum dated about 125-150 AD. ${ }^{41}$ They have a lot in common; especially the curly hairstyle on the forehead, and also the treatment of the full beard with short tufts.

The adherence to the Hadrianic traditions of portraiture like the wavy and curly hair locks with the full beard and moustache with their finely worked short tufts may support the proposed early Antonine date. ${ }^{42}$

\section{Conclusion:}

The portrait-head from Kom Ombo is important for Roman Egypt studies because it adds Kom Ombo to the main centers connected with the Emperors-portraits discoveries, like Alexandria, Atribis and Middle-Egypt nomos.

The image of Antonius Pius has been thought to be not as common in stone arts, in particular the round sculpture, as it was in coins. Now this Kom Ombo head may change such a view about Antoninus Pius representations in Egypt, as it attests that Antoninus Pius was a beloved emperor in Egypt and received imperial cult in Kom Ombo.

It can be asserted that some of the portraits found in provinces were made there. Such distinct differences between the Kom Ombo portrait-head and other examples of the same type, especially the el-Ashmunein's head, indicate that Kom Ombo's portrait-head was not carved in the same workshop, and that the portrait reflects a regional artistic taste.

As both the temple of August at Philae and the imperial cult shrine in front of the first pylon of the Amun temple at Karnak are located in the vicinity of the main native Egyptian temples, similarly it may be suggested that the portrait of Kom Ombo with its bust or statue was erected in a Roman-style shrine for the imperial cult located outside the main Egyptianstyle temple where many native practices and beliefs were adopted, though the imperial cult was still being classified as a Roman cult.

\footnotetext{
${ }^{41}$ DOXIADIS 1995, P. 188, no. 18.

${ }^{42}$ BORG 1996, p. 76.
} 


\section{Abdel Hamid Masoud}

\section{BIBLIOGRAPHY:}

- Ashton, S.-A. 2004, Roman Egyptomania, Golden House Publications.

- Borg, B. 1996, Mumienporträts: Chronologie und kultureller Kontext, Philipp von Zabern: Mainz am Rhein.

- Cooney, J. D. 1967, "A Roman Imperial Head from Egypt", the Bulletin of the Cleveland Museum of Arts, vol. 54, no. 1 (Jan. 1967,), pp. 17-21.

- Doxiadis, E. 1995, The Mysterious Fayum Portraits: Faces from Ancient Egypt, Thames and Hudson.

- Dundas, G. S. 1994. Pharaoh, Basileus and Imperator: the Roman imperial cult Egypt, Doctoral dissertation, University of California, Los Angles.

- Fishwick, D. 1989, "Statues taxes in Roman Egypt", Historia: Zeitschrift für Alte Geschichte, Bd 38, H. 3, pp. 335-347.

- Fittschen, K. \& Zanker, P. 1985, Katalog der römischen Porträts in den Capitolinischen Museen und den anderen kommunalen Sammlungen der Stadt Rom, Series: Beiträge zur Erschliessung hellenistischer und kaiserzeitlicher Skulptur und Architektur, Band 3, Mainz am Rhein: Philipp von Zabern.

- Frankfurter, D. 1998, Religion in Roman Egypt, Assimilation and resistance, Princeton University Press.

- Graindor, P. 1936, Bustes et statues-portraits d'ÉGypte Romaine, Le Caire.

- Grimm, G. 1975, Kunst der Ptolemäer- und Römerzeit im Ägyptischen Museum Kairo, Mainz am Rhein.

- Hǿjte, J. M. 2000, "Imperial visits as occasion for the erection for portrait statues?", Zeitschrift für Papyrologie und Epigraphik 133, Bonn, 2000.

- Hölbl, G. Altägypten im römischen Reich: der römische Pharao und seine Tempel, Band 1: Römische Politik und altägyptische Ideologie von Augustus bis Diocletian, Tempelbau in Oberägypten (Zaberns Bildbände zur Archäologie), Mainz am Rhein.

- Inan, J. \& Rosenbaum, E. 1966, Roman and early Byzantine portrait sculpture in Asia Minor, London: Oxford University Press for the British Academy.

- Kamel, J. 1993, Aswan and Abu Simbel: History and Guide, The American University in Cairo Press.

- Kiss, Z. 1984, Études sur le Portrait Impérial Romain en Egypte, Varsovie. 


\section{A new portrait-head of Antoninus Pius from Egypt}

- Kleiner, E. E. D. 1992, Roman Sculpture, Yale University Press, New Haven \& London.

- Macquity, W. 1976, Island of Isis, Philae temple of the Nile, London.

- Markot, R. 2001, "Kom Ombo", in: D. B. Redford, (ed.), the Oxford Encyclopedia of Ancient Egypt, vol. 2, Oxford University Press.

- McKenzie, J. 2007, The Architecture of Alexandria and Egypt: c 300 BC to $A D$ 700, Yale University Press - New Haven \& London.

- Newsletter of the Egyptian Ministry of Antiquities, 2018, Issue 23, Cairo, April.

- Opper, Th. 2010, Hadrian: Empire and Conflict, Harvard University Press.

- Pfeiffer, S. 2010, Der römische Kaiser und das Land am Nil, Kaiserverhrung und Kaiserkult in Alexandria und Ägypten von Augustus bis Caracalla (30 v. Chr.-217 n. Chr.), Franz Steiner Verlag Stuttgart,.

- Pfeiffer, S. 2012, "The Imperial cult in Egypt", in: Ch. Riggs, (ed.), The Oxford Handbook of Roman Egypt, Oxford University Press,.

- Portman, I. 2001, A guide to the temple of Kom - Ombo, Cairo.

- Porter, B. \& Moss, R. L. B. 1991, Topographical bibliography of ancient Egyptian hieroglyphic texts, reliefs, and paintings, VI, Upper Egypt: chief temples, (excluding Thebes): Abydos, Dendera, Esna, Edfu, Kom Ombo, and Philae, Ashmolean Museum, Oxford.

- Brophy, E. 2015, Royal Statues in Egypt 300 BC-AD 220: Context and Function, (Archaeopress Egyptology 10) Oxford.

- Sartre, M. 1997, "Le préfet, le stratège et le nome", in: Réunion des Musées Nationaux (ed.), Égypte romaine: l'autre Égypte, Musées de Marseille - Réunion des Musées Nationaux.

- Walker, S. 1995, Greek and Roman Portraits, British Museum Press.

- Walker, S. \& Higgs, P. 2001, Cleopatra of Egypt from History to Myth, British Museum.

- Wegner, M. 1939, Die Herrscherbildnisse in antoninischer Zeit, Das römische Herrscherbild II, 4, Berlin.

- Vermeule, C. C., "Roman Art", Art Institute of Chicago Museum Studies 20, no. 1, pp. 62-77.

- Wilkinson, R. H. 2000, The complete temples of ancient Egypt, Thames \& Hudson.

- Willeitner, J. 2003, Die ägyptischen Oasen, Städte, Tempel und Gräber in der libybischen Wüste, Maniz am Rhein. 


\section{Abdel Hamid Masoud}

- Wissowa, G., et al. (eds.), 1909, Paulys Realencyclopädie der classischen Altertumswissenschaft: neue Bearbeitung, Stuttgart.

- Otto, W. G. A. 1905, Priester und tempel im hellenistischen Ägypten: en beitrag zur kulturgeschichte des hellenismus, 1 Bd., Leipzig und Berlin.

- Otto, W. G. A. 1908, Priester und tempel im hellenistischen Ägypten: en beitrag zur kulturgeschichte des hellenismus, II Bd., Leipzig und Berlin. 


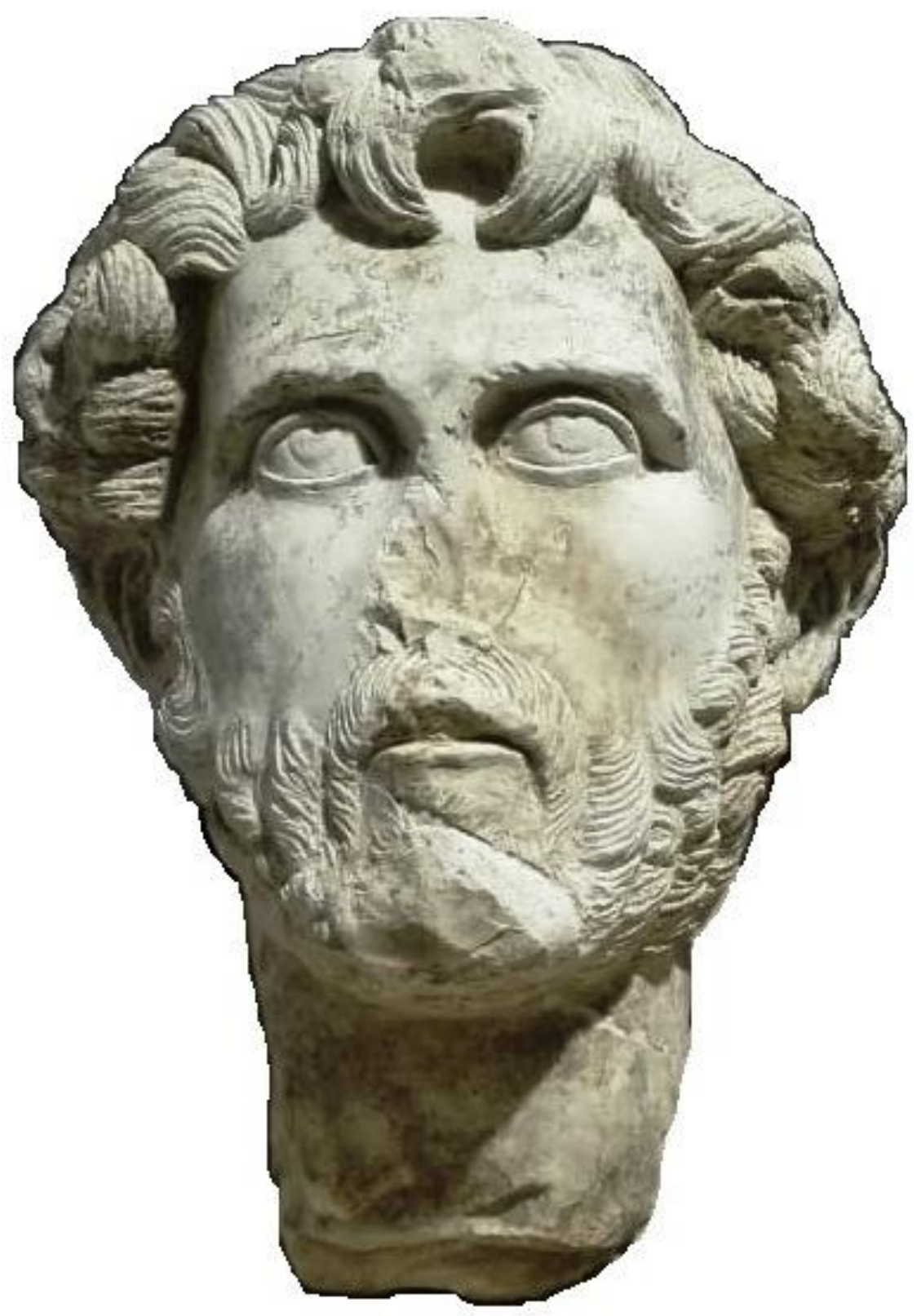

Fig. 1 


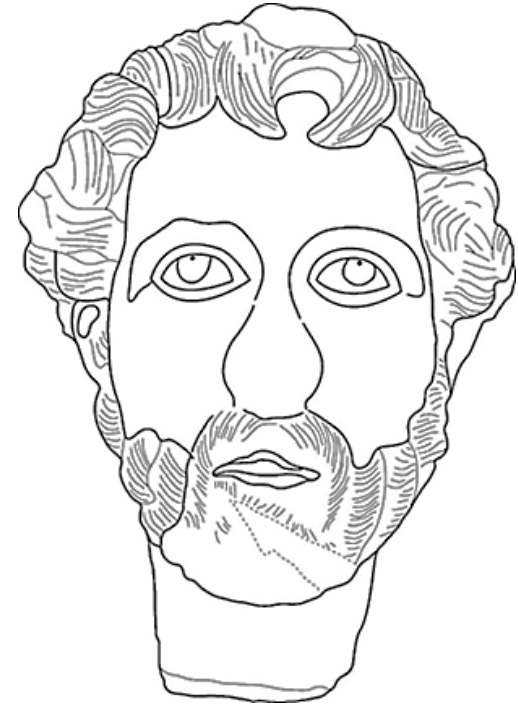

Fig. 2

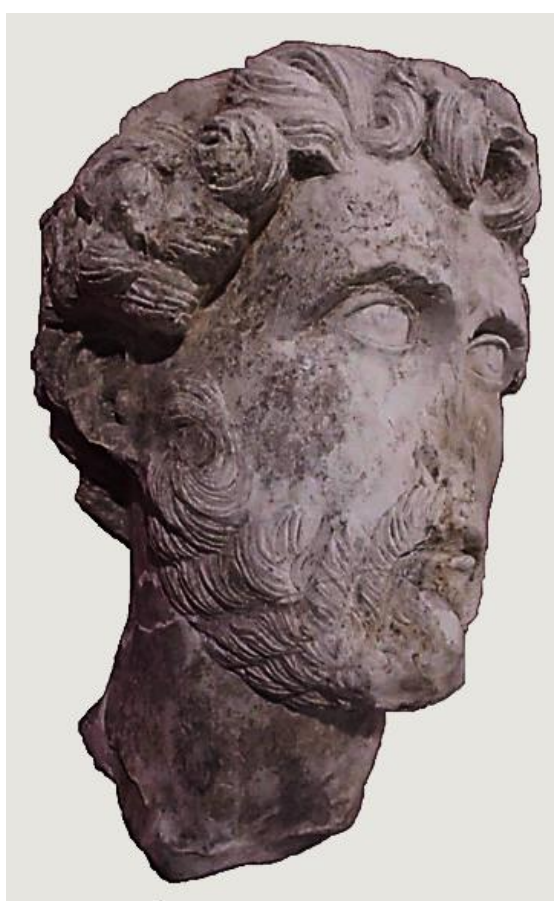

Fig. 4

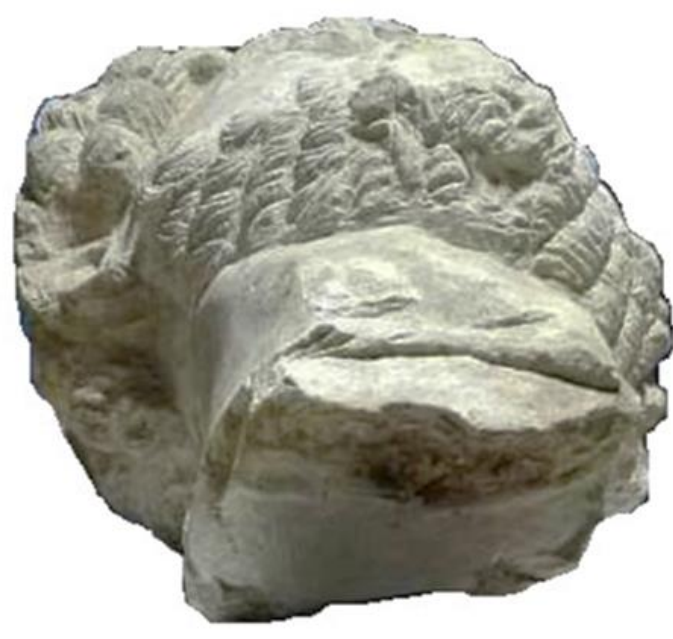

Fig. 3

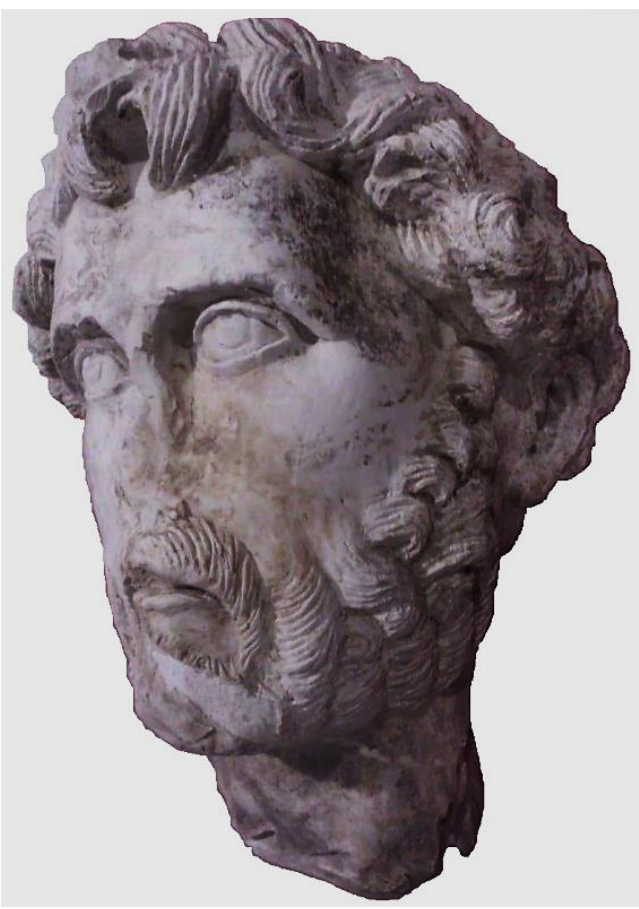

Fig. 5 
A new portrait-head of Antoninus Pius from Egypt

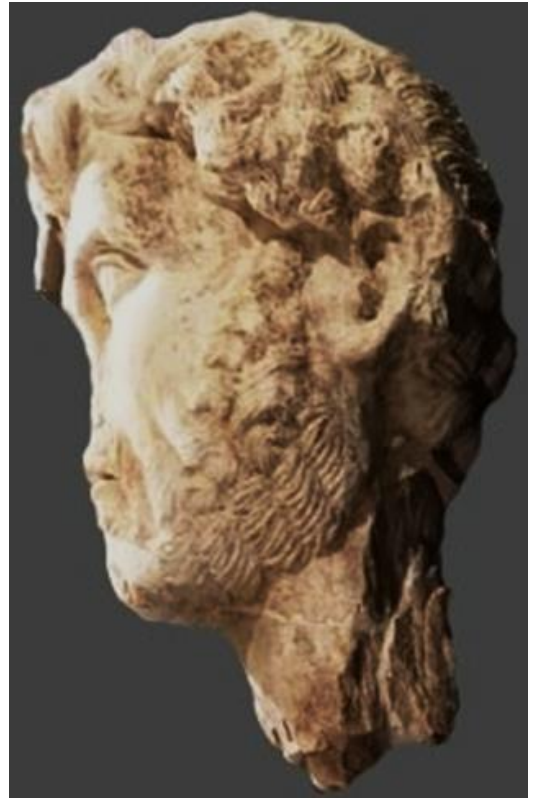

Fig. 6

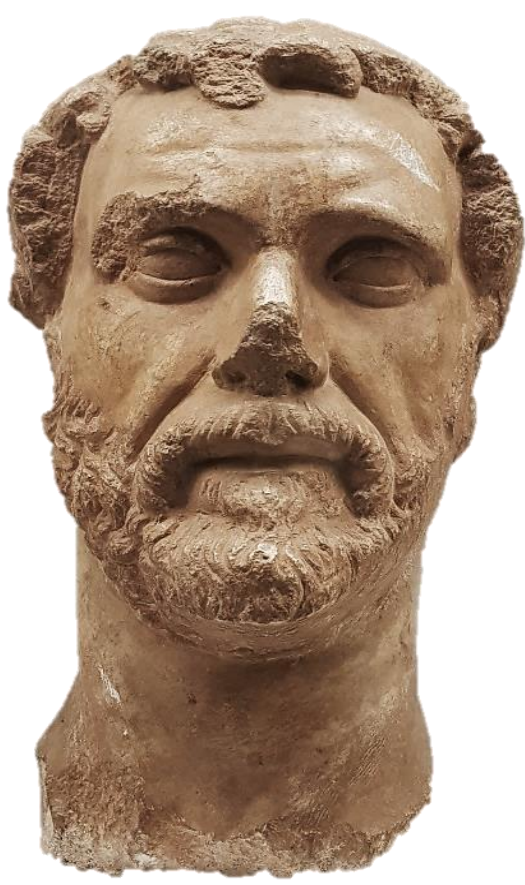

Fig. 8

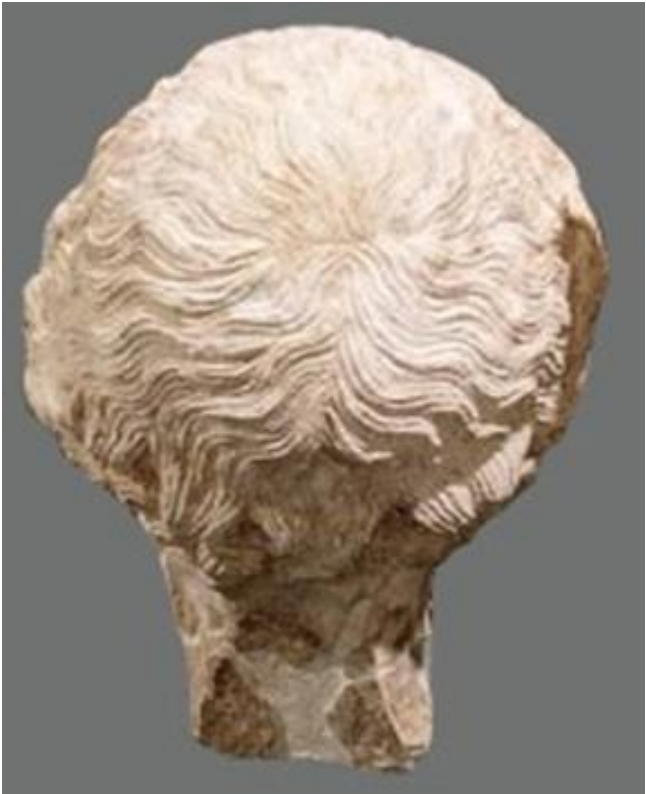

Fig. 7

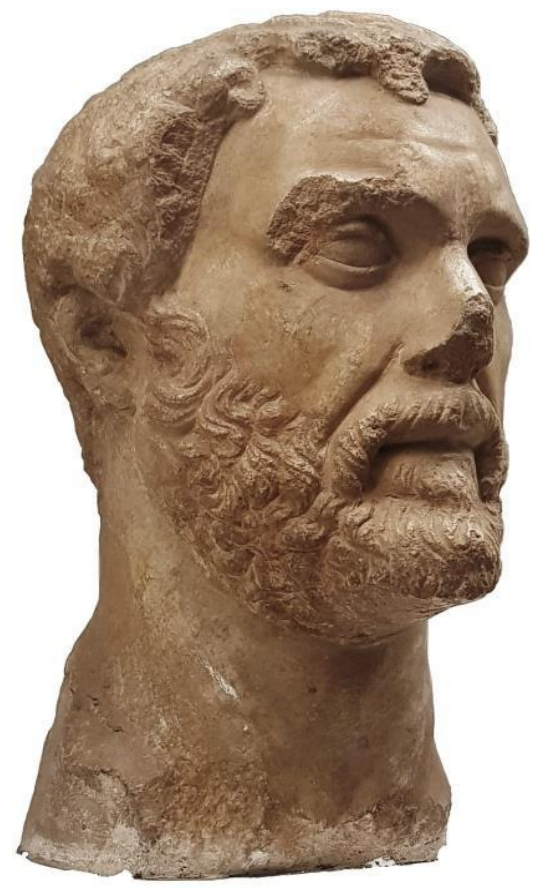

Fig. 9 